Wanda Fijałkowska

Uniwersytet Warszawski, Warszawa

w.fijalkowska@uw.edu.pl

\title{
CZY DERYWATY PREFIKSALNE WYMIENNE WYRAŻAJĄ INTENSYWNOŚĆ?
}

Słowa klucze: czasownik dokonany, derywacja, wymiana prefiksów, intensywność, efektywność Keywords: perfective verb, derivation, exchange of prefixes, intensity, effectiveness

1. Zbiór formacji prefiksalnych wymiennych, powstałych jako rezultat działania nieznanej (do 2003 r.) słowotwórstwu synchronicznemu techniki derywacyjnej, nie był, bo nie mógł być, przedmiotem syntetycznego opisu semantycznego. Jedyna całościowa klasyfikacja znaczeniowa czasowników polskich autorstwa Henryka Wróbla $(1984,1998)$ dotyczy kategorii części mowy, nie zaś - podzbioru leksemów wyodrębnionego na mocy kryteriów słowotwórczych. Pionierska praca Michała Wiśnickiego taką propozycję zawiera ${ }^{1}$, ale jest ona właściwie adaptacją siatki pojęciowej Witolda Śmiecha (1986) i Henryka Wróbla² do potrzeb konkretnego materiałus.

1 Najobszerniejszą wersję znajdziemy w niepublikowanej rozprawie doktorskiej, por. Wiśnicki 2010. Za łaskawe udostępnienie mi elektronicznej wersji monografii składam Autorowi serdeczne podziękowanie.

2 Chodzi tylko o propozycje przedstawione w: Wróbel 1998.

3 Wiele ważnych spostrzeżeń na temat znaczenia czasowników przedrostkowych zawiera monografia Renaty Przybylskiej (2006). Ponieważ jednak problem ten został w monografii przedstawiony w ujęciu kognitywnym, kierunek poszukiwań badawczych autorki i Wiśnickiego jest odrębny, prace mają też różną bazę materiałową. Niekwestionowaną wartością analiz Przybylskiej jest bogata dokumentacja przykładowa. Jej ubóstwo w Morfologii nie sprzyja szczegółowym dociekaniom, a tym bardziej nie upoważnia do uogólnień. 
Według jego definicji

[...] derywacja prefiksalna wymienna polega na usuwaniu prefiksu z podstawowego czasownika dokonanego (podzielnego słowotwórczo) i zastępowaniu go innym przedrostkiem w pochodnym czasowniku dokonanym (Wiśnicki 2010: 44)4.

Formacje poddane opisowi semantycznemu muszą więc być czasownikami dokonanymi od podstaw o tych samych cechach, a ich jedynym wykładnikiem słowotwórczym może być przedrostek. Pomijamy zatem struktury prefiksalno-postfiksalne, jak np. napracować się $\leftarrow$ pracować. Typowe zaś leksemy poddane analizie to: przejeść się $(\leftarrow$ najeść się), wyniszczyć $(\leftarrow$ zniszczyć), dobudować $(\leftarrow$ zbudować), odrysować $(\leftarrow$ narysować), przebrać $(\leftarrow$ ubrać), oddzwonić $(\leftarrow$ zadzwonić), pomierzyć $(\leftarrow$ zmierzyć), rozlokować $(\leftarrow$ ulokować), wylogować się $(\leftarrow$ zalogować się), nagotować $(\leftarrow$ ugotować).

Poszczególne części opisu semantycznego derywatów prefiksalnych wymiennych mają bardzo różną wartość naukową. Do większości z nich nie można mieć najmniejszych zastrzeżeń, stanowią bowiem podzbiór wyłoniony po zastosowaniu przejrzystych kryteriów znaczeniowych, w niektórych wypadkach nawet idealnie harmonizujących z budową słowotwórczą analizowanych struktur. Są jednak i takie, których rozpoznanie semantyczne oraz skład leksykalny trzeba poddać krytyce.

Za całkowicie akceptowalne należy uznać podgrupy o znaczeniu:

- dystrybutywnym: pomyć ( $\leftarrow$ umyć);

- anulatywnym: odkleić ( $\leftarrow$ przykleić);

- suplementarnym: doczepić $(\leftarrow$ przyczepić);

- transformatywnym: przebrać $(\leftarrow u b r a c ́)$;

- restauratywnym: odbudować $(\leftarrow z b u d o w a c ́)$;

- repetytywnym: przepisać ( $\leftarrow$ napisać);

- reaktywnym: oddzwonić ( $\leftarrow$ zadzwonić).

W ich składzie znalazła się większość analizowanego materiału (około 80\%).

2. Powtórnej analizy wymagają derywaty nazywające intensywność akcji, efektywność działania, metodyczność czynności, kompletywność działania oraz ukierunkowanie czynności.

Kategorie te, jako mało liczebne, stoją wprawdzie nisko w hierarchii, ale korekta ich zakresu semantycznego oraz składu leksykalnego może udoskonalić również tę mniej ważną część opisu. Niewykluczone też, że zmiany zaszeregowania pewnych derywatów zwiększą przejrzystość prezentacji słowotwórczej

Najwięcej zastrzeżeń budzą leksemy uznane przez Wróbla za derywaty oznaczające „intensywność” i „efektywność akcji”, a przez Wiśnickiego nazwane czasownikami „intensywności akcji”; one właśnie pozostaną w centrum naszej uwagi.

4 Wcześniejsza wersja definicji (por. Wiśnicki 2009: 139) nie eksponuje jeszcze dokonaności podstaw i derywatów. Ta modyfikacja jest bardzo istotna. 
Wątpliwości powstają już przy definiowaniu zjawiska intensywności. Słowniki ogólne zgodnie i jednoznacznie określają przymiotnik intensywny jako 'mający duże natężenie; wzmożony, wzmocniony' (SJPSz) lub podobnie 'mający duże natężenie; mocny, silny' (USJP). Rzeczownik intensywność przejmuje cechy semantyczne podstawy. Z przytoczonych definicji wynika pośrednio, że jeśli uznajemy czasownik za nazywający intensywność akcji, uznajemy tym samym wyrażane przez niego działanie za długotrwałe i/lub wymagające użycia dużej siły.

Autorzy opisujący tę kategorię semantyczną poświęcają najwięcej uwagi derywatom $\mathrm{z}$ formantem prze- (przekarmić $\leftarrow$ nakarmić, przepłacić $\leftarrow$ zapłacić, przesolić $\leftarrow$ $\leftarrow$ posolić, przejeść się $\leftarrow$ najeść się, przegrzać $\leftarrow$ ogrzać, przeinwestować $\leftarrow$ zainwestować). Wiśnicki twierdzi, że „informują o uintensywnieniu czynności wyrażonej podstawą", a ponadto "pojawia się w nich komponent znaczeniowy informujący o wystąpieniu negatywnych skutków związanych z podjętą czynnością" (2009: 144). Śmiech charakteryzuje takie struktury ostrożniej: 'przesadzić w wykonywaniu czynności, przebrać miarę’ (1986: 65-66), Wróbel zauważa tylko, że

[...] formanty prefiksalne i prefiksalno-postfiksalne mogą charakteryzować stopień intensywności akcji podstawowej w sposób bezwzględny albo przez odwołanie się do przyjętej dla danej akcji normy. W obu wypadkach wyróżniamy stopień wysoki (wzmocniony) i słaby (osłabiony) (Wróbel 1998: 550).

O ile ze stanowiskiem Śmiecha można się jeszcze zgodzić, o tyle poglądy Wróbla i Wiśnickiego na temat tych struktur nie przekonują z trzech powodów:

a) po pierwsze, wymienione formacje z prefiksem prze- oraz niektóre inne składniki tej grupy nie nazywają intensywności czynności;

b) po drugie, nie ma w nich informacji o wystąpieniu jakichkolwiek negatywnych skutków wskazywanych czynności;

c) po trzecie, w wyrażeniu „słaby stopień intensywności” tkwi sprzeczność logiczna. Udowodnienie tych twierdzeń jest głównym celem niniejszego artykułu.

2.1. W sprawie pierwszej odwołajmy się do kilku przykładów spośród 55 zarejestrowanych przez Wiśnickiego (2010: 193).

a) Czasownik przepłacić niewątpliwie niesie sens 'zapłacić zbyt dużo', ale nie ma to związku z naturą czynności płacenia, nie da się bowiem wykazać, na czym miałaby polegać jej intensywność. Nie wchodzą w grę ani długość operacji finansowej, ani wysiłek fizyczny. Przepłacamy, czyli 'wykraczamy poza przewidzianą dla danego produktu normę cenową przez niedoświadczenie albo z konieczności.

b) Przesolić to 'posolić nadmiernie, czyli wsypać do potrawy więcej soli (według czyjegoś subiektywnego gustu), niż potrzeba, by przygotować smaczne danie’. Nie można udowodnić, że sprawca tej niedogodności kulinarnej długo, długo coś solił, aż zmęczył się tą ciężką pracą. Na ogół bowiem dochodzi do tego przez (chwilową!) nieuwagę lub z braku praktyki.

5 Obecnie ich liczba jest znacznie wyższa. 
c) Definicja czasownika przetrzymać 'zatrzymać kogoś lub coś na dłużej niż trzeba lub niż było przewidziane’ (USJP, zn. 3.) jeszcze dobitniej niż poprzednie wskazuje na błąd w jego klasyfikacji semantycznej, gdyż wiele jego użyć nie tylko nie podkreśla włożonego wysiłku, lecz także wskazuje na niepodjęcie żadnego działania. W USJP znajdujemy takie m.in. przykłady: Owoce przetrzymane na drzewie zaczęly gnić (= nikt ich nie zerwał); Przetrzymać wagony na stacji (= nic nie zrobić, żeby opuściły dworzec); Przetrzymać książkę z wypożyczalni (= nie oddać).

d) Dowodów na intensywność wyrażanej czynności nie dostarcza także definicja derywatu prześwietlić fot. 'nadmiernie naświetlić emulsję fotograficzną'.

e) Również formacja przechwalić pot. 'przesadzić w chwaleniu kogoś, czegoś, mówić o kimś ze zbyt wielkim uznaniem, pochwalić zanadto, bardziej niż ktoś, coś na to zasługuje' (USJP), nie informuje ani o długim, ani o męczącym chwaleniu. Przesadna pochwała może się wiązać z użyciem jednego wyrazu oceniającego kogoś nieadekwatnie do zasług, por. Proponowane rozwiązanie jest genialne czy Nie zapomnimy o pańskich wiekopomnych sukcesach.

$\mathrm{W}$ podobny sposób można zakwestionować przynależność pozostałych derywatów przedrostkowych wymiennych (nadważyć, nadpłacić, nadmierzyć) do leksemów nazywających nadmierną intensywność czynności.

Negatywne skutki, wielokrotnie podkreślane w rozprawie Wiśnickiego (2010: 86, $89,196)$, to domniemane następstwo czynności wskazanych przez te czasowniki, nie zaś ich komponent semantyczny, przy czym przypisywany im element oceny jest w rzeczywistości składnikiem pragmatycznym (aksjologicznym), nie zaś znaczeniowym. Dodajmy dla ścisłości, że nie zawsze musi on być negatywny, szczególnie w odległej perspektywie czasowej.

Takie wyrażenia, jak „słaba intensywność”, „niski stopień intensywności” po prostym skonfrontowaniu $\mathrm{z}$ definicją przymiotnika intensywny okazują się treściowo niedorzeczne.

2.2. Do leksemów nazywających wysoki stopień intensywności akcji Wróbel zaliczył jak najsłuszniej między innymi formacje słowotwórcze uśmiać się, ubawić się, wybiegać się, spłakać się, wczuć się, zastuchać się (1998: 549) Te i podobne struktury nie wchodzą jednak w zakres naszych badań jako derywowane od czasowników niedokonanych formantem prefiksalno-postfiksalnym. Nieliczne wyrazy również włączone do tej grupy, teoretycznie wyprowadzalne od czasowników przedrostkowych dokonanych, budzą inne zastrzeżenia i wymagają indywidualnego komentarza.

Czasowniki obkarmić, opoić6 trudno uznać za leksemy należące do współczesnej polszczyzny ogólnej. Znajdziemy je wprawdzie w Słowniku gniazd słowotwórczych (SGS), ale już USJP je pomija. Leksem wymarznać, jeśli w ogóle jest dziś używany w znaczeniu 'bardzo zmarznąć', to raczej w formie wymarznać się (Okropnie się wy-

6 Ich źródłem jest SJPD, przy czym czasownik opoić jest tam kwalifikowany jako przestarzały. 
marzłam na przystanku), co go eliminuje z naszych analiz, podobnie jak czasowniki przytoczone wyżej. Z kolei wyraz obrodzić 'dać obfity plon', mimo przejrzystości słowotwórczej, nie jest derywatem ani od czasownika urodzić, ani rodzić. Ostatni $\mathrm{z}$ wątpliwych przykładów to formacja umęczyć, łączona dziś semantycznie z czasownikiem $z a m e ̨ c z y c^{\prime}$, ale jedynie jako synonim.

$\mathrm{Na}$ liście formacji wyrażających „czystą intensywność” znalazły się u Wiśnickiego (2010: 86, 87) leksemy wybawić się, wybrudzić, wychwalić, wygłodnieć, wynudzić, wyziębnąć, zeschnąć. Z tego zestawu musimy usunąć derywat wychwalić $(\leftarrow$ pochwalić) ze względów chronologicznych ${ }^{8}$. Pozostałe czasowniki nie mają, naszym zdaniem, definicji uzasadniających taką kategoryzację semantyczną ani wzmacniających ją kontekstów.

W leksemie wybawić się pot. 'użyć zabawy, nabawić się do woli' (USJP) najważniejszy jest składnik znaczeniowy 'do woli', który eksponuje osiągnięcie oczekiwanego efektu, maksymalne zaspokojenie potrzeby zabawy. W czasowniku wybrudzić dominuje komponent ' $w$ wielu miejscach', element 'bardzo' jest fakultatywny, wyraźnie drugoplanowy. Zdanie ${ }^{\star} W y b r u d z i t$ się tylko na mankiecie uznalibyśmy za dewiacyjne.

Wygłodnieć to 'nie jedząc przez dłuższy czas, stać się bardzo głodnym' (USJP), wyziębnąc 'stać się zimnym, stracić ciepło, ostygnąć'. Pokój wyziąbł w czasie mrozu. Herbata wyziębła (USJP). Zeschnać to 'obumrzeć z braku wody'. Zboże zeschło na polu (USJP). Czasownik wynudzić 'zmęczyć kogoś nudzeniem' (Wynudzić kogoś rozwleklym opowiadaniem; USJP) informuje o niezamierzonym efekcie nieciekawych działań9.

Definicje i konteksty wskazują na stopniowe podleganie pewnemu stanowi, nie zaś - na intensywne działanie (herbaty?). Schemat interpretacji semantycznej może mieć tu związek ze znaczeniem podstaw niebędących czasownikami.

Wszystko wskazuje na to, że również określenia „czystej intensywności” nie spełniają warunków definicyjnych. Naszym zdaniem, analiza żadnego derywatu spośród wytypowanych przez autora do tej kategorii nie prowadzi do wniosku, że konstytutywnym składnikiem semantycznym jest w nim intensywność.

Czasowniki opisane jako nazywające „słabą intensywność” usuwamy z tej grupy ze względów logicznych (por. s. 73). Dodajmy na marginesie, że również stopniowanie środkami morfologicznymi przebiega od znaczenia podstawowego w górę. Gradacja intensywności jest oczywiście możliwa (osoba X może pracować $\mathrm{z}$ większą intensywnością, szybciej i wydajniej niż osoba Y), ale ma zakres ograniczony do strefy przewyższającej średnie natężenie.

7 USJP: umęczyć 2. podn. 'męcząc, torturując pozbawić kogoś życia, zamęczyć'. Umęczenie Chrystusa na krzyżu.

8 Leksemu brak w USJP, w SJPD jest on natomiast opatrzony kwalifikatorem daw., a ilustrowany cytatem z 1846 r. oraz z Monachomachii.

9 Ewentualny wysiłek był przecież skierowany w przeciwną stronę. 
Pora więc postawić pytanie: jaką kategorię semantyczną reprezentują wymienione derywaty, skoro nie jest nią intensywność?

3. Aby na nie odpowiedzieć, trzeba przywołać kategorię efekty w ności, połączoną wprawdzie przez Wróbla z intensywnością, ale wyraźnie zmarginalizowaną, przez Wiśnickiego natomiast po prostu zbagatelizowaną. Tymczasem właśnie ta kategoria wymaga skontrastowania $\mathrm{z}$ intensywnością.

Działania intensywnego, które trwa długo i/lub wymaga użycia dużej siły ${ }^{10}$, nie należy mylić ani z czynnością o rozległym zakresie (Wytruliśmy szkodniki), ani o pożądanym skutku (Dopraliśmy ubrania). Nie ma dowodu, że wytrucie szkodników czy dopranie odzieży wiązało się z długotrwałym, mozolnym działaniem. Mogło do tego dojść dzięki błyskawicznie działającym środkom chemicznym. Wskazane rezultaty czynności to (zamierzone lub nie) efekt y pewnej pracy.

W odróżnieniu od intensywności efektywność jest „obustronnie” stopniowalna, to znaczy planowany skutek może być osiągnięty w stopniu podstawowym oraz częściowym, nadmiernym, wysokim i maksymalnym.

Aby to udowodnić, sięgnijmy po materiał leksykalny.

Osiągnięcie pożądanego skutku (= oczekiwanego efektu) nazywają m.in. czasowniki: nauczyć, otruć, posolić, umyć, uprać, wyleczyć, zapłacić, zmierzyć, będące podstawami motywacyjnymi czterech typów derywatów modyfikujących efekt wyjściowy.

3.1. Jeżeli chcemy scharakteryzować uzyskanie efektu w wysokim stopniu, dysponujemy leksemami: wygolić, wysmagać, obrewidować, odczyścić, odszlifować (Wróbel 1984: 476), aby nazwać go adekwatnie.

3.2. Jeżeli efekt jest zbyt duży w stosunku do postawionego celu, modyfikujemy znaczenie podstawy prefiksem prze-: przesolić $(\leftarrow$ posolić), przeinterpretować $(\leftarrow z i n-$ terpretować), przepłacić ( $\leftarrow$ zapłacić), przejeść się ( $\leftarrow$ najeść się), rzadziej za-, s-: zapić się, spić się ( $\leftarrow$ upić się).

3.3. Poza kategorią semantyczną intensywności sytuuje Wróbel formacje kompletywne, o których pisze, że powstają za pomocą prefiksu wy-(rzadziej o(b)-) i charakteryzują ilość akcji przez ogarnięcie nią wszystkich przedmiotów danej zbiorowości, np. wygasić (światła), wyłapać, wytruć (muchy), wyginać (np. o rodzie), wygnić (np. o ziemniakach), obczęstować (gości)) (Wróbel 1998: 549).

Wiśnicki umieszcza tego typu struktury (oprócz wyżej wymienionych także: $w y$ bić, wychwytać, wyciąć, wydławić, wydusić, wygubić, wymrzeć, wytracić) wśród „czasowników dystrybutywnych o specyficznym znaczeniu" (Wiśnicki 2010: 56) ${ }^{11}$. Przypomnijmy jednak, że wyróżnikiem znaczeniowym licznej (452 derywaty) kategorii dystrybutywności jest nazywanie działania podejmowanego w odniesieniu do wielu

10 Por. Strasznie się z niego uśmieliśmy. Napracowaliśmy się porządnie w ogrodzie.

11 W dalszej części pracy (s. 160) zwraca jeszcze uwagę na to, że duża część tego podzbioru to „czasowniki destrukcji”. 
przedmiotów lub do większej ich liczby (Wiśnicki 2009: 142). Tymczasem przywołane derywaty wskazują na działanie obejmujące wszystkie elementy danego podzbioru. Nie bez znaczenia jest także fakt, że większość struktur dystrybutywnych ma formant na- lub po-, zatem pozostawienie wśród nich formacji z wy-zakłóca jednorodność słowotwórczą tej grupy. $Z$ tych powodów, a także ze względu na niewielką liczebność formacji wyróżnionych jako kompletywne, uznałabym również tę grupę leksemów za jednolitą formalnie część czasowników nazywających efektywność akcji. Przemawia za tym także to, że wskazują one na skończony, nieprzekraczalny skutek działania, czyli efektywność maksymalną.

3.4. Jak już wspomniano, efekt czynności, inaczej niż intensywność, może być także niewielki. Kiedy jednak, już po tej korekcie terminologicznej, przystępujemy do analizy formacji objętych taką nazwą nadrzędną, pojawia się następny problem, związany z propozycjami klasyfikacyjnymi Wróbla, przejętymi również przez Wiśnickiego. Obaj autorzy wychodzą z założenia, że derywatom nazywającym wysoki stopień intensywności (u nas - efektywności) odpowiadają "na drugim biegunie” formacje charakteryzujące niską efektywnośćc ${ }^{12}$. Ta swoista symetria zachodzi jednak tylko na poziomie semantycznym. Rozciąganie jej na płaszczyznę słowotwórczą prowadzi do błędu interpretacyjnego.

Łatwo to wykazać na przykładzie derywatów od czasowników bazowych TRUĆ i LECZYĆ.

W gnieździe pierwszego z nich znajdziemy m.in. derywaty otruć, natruć, podtruć, potruć, wytruć. Standardowa analiza słowotwórczo-semantyczna formacji natruć, potruć, wytruć prowadzi do ich przyporządkowania bezpośredniej podstawie motywującej otruć, ze wskazaniem dużej (natruć, potruć), a nawet maksymalnej efektywności (wytruć). Per analogiam „małą efektywność” („małą intensywność”) przypisalibyśmy leksemowi podtruć z tą samą podstawą motywującą. Jest to jednak wnioskowanie niepoprawne, bowiem parafraza 'otruć częściowo, trochę' jest logicznie sprzeczna. Podtruć to 'wprowadzić do organizmu małą dawkę trucizny, zatruć częściowo', zatruć to z kolei 'dodać do czegoś trucizny' (USJP). Parafraza słowotwórcza powinna mieć postać 'zacząć truć, próbować truć itp'.

Drugi z badanych derywatów jest podstawą motywującą synonimicznych czasowników uleczyć i wyleczyć. W tym samym gnieździe słowotwórczym znajdziemy formacje podleczyć i zaleczyć, których jednak nie można parafrazować 'uleczyćl wyleczyć trochę, częściowo', gdyż wyleczenie oznacza 'ostateczny, pozytywny, skończony efekt kuracji', zatem nie może być „częściowe”. Podleczyć należy więc opisywać 'poprawić leczeniem czyjś stan zdrowia ${ }^{13}$, a zaleczyć - 'lecząc, zatrzymać proces

12 Wróbel jednak nie sytuuje ani derywatów intensywności akcji, ani efektywności akcji wśród struktur prefiksalnych wymiennych.

13 W praktyce używamy czasownika wyleczyć z naciskiem na zastosowane środki; uleczyć używany jest także w odniesieniu do sytuacji medycznie niewytłumaczalnych (cudem uleczony). 
rozwoju choroby’. Taki właśnie kształt ma pierwsza część definicji tego leksemu w USJP. Jednak już dodatek 'wyleczyć kogoś lub coś do pewnego stopnia' jest zbędny. Ani otruć, ani wyleczyć nie można „trochę, niezupełnie, częściowo”. Stawianie derywatów podtruć, podleczyć, zaleczyć w jednym szeregu motywacyjnym z wytruć, wyleczyć jest jedną $\mathrm{z}$ wielu nieuprawnionych ekstrapolacji $\mathrm{w}$ analizach leksemów czasownikowych. Skoro więc nie ma bezpośredniej zależności formalnej między wyrazami podtruć, zatruć a otruć oraz między podleczyć i zaleczyć a wyleczyć, a zachodzi ona między podtruć, zatruć a truć, podobnie jak między podleczyć, zaleczyć a leczyć, nie są one derywatami prefiksalnymi wymiennymi, w przeciwieństwie do formacji z formantami $n a-, p o-, w y-$.

4. Między Wróblem a Wiśnickim ujawniły się różnice poglądów na temat zakresu kategorii intensywności. Wśród leksemów włączonych do niej przez Wróbla Wiśnicki dostrzegł dwie różne podklasy, zasługujące na odrębny opis: „intensywne właściwe" oraz zawierające składnik semantyczny 'metodyczność (staranność)'. Jego zdaniem, niewielka grupa czasowników (27) ma taką właśnie dominantę semantyczną. Swoją decyzję uzasadnia następująco:

Czym innym [...] jest podkreślanie, że jakaś czynność została wykonana (zbyt) intensywnie, [...] czym innym natomiast informowanie przede wszystkim o wykonywaniu czynności dokładnie, w sposób metodyczny, przemyślany (Wiśnicki 2010: 106).

W odróżnieniu od autora nie widzę w tych formacjach ani intensywności (o czym była mowa wcześniej), ani metodyczności. W komentarzu ograniczę się tylko do grupy struktur z ob(e)-: ob-<>jeść, ob-<>mazać, ob-<>mierzyć, ob-<>myć, ob-<>sadzić, $o b-<>s z u k a c ́, o b(e)-<>\dot{z} r e c ́$.

Najwięcej zastrzeżeń budzi derywat obmazać; już jego podstawa kontrastuje ze składnikiem semantycznym 'dokładnie, starannie'. Potwierdza to opis leksykograficzny: 'wybrudzić lub posmarować coś dookoła, z wielu stron' (USJP), a umacniają przywołane użycia: Obmazać ściane farbą. Twarz obmazana sadzą. Leksem obmyć definiowany jest jako 'umyć coś, kogoś niestarannie, tylko z grubsza, spłukać brudną powierzchnię’. W obsadzić widziałabym przede wszystkim komponent 'dookoła', w czasownikach objeść, obeżreć 'do końca, kompletnie', a w obszukać - 'kolejno, w wielu miejscach', por. Obszukał wszystkie kąty bez rezultatu; Obszukać cały dom (USJP).

Jedynym derywatem tej grupy, który może mieć w swoim znaczeniu składnik 'metodycznie, starannie', jest obmierzyć. Jednak z faktu, że jego opis słownikowy uzupełnia kontekst Dokładnie coś obmierzyć (= Dokładnie zmierzyć coś dokładnie), wynika pośrednio, że nie jest to oczywista dominanta znaczeniowa.

Powinniśmy zatem:

a) włączyć czasowniki objeść, obeżreć i ewentualnie obmazać do grupy nazywającej maksymalną efektywność,

b) obmyć usytuować wśród określeń niskiej efektyw ności, 
c) obsadzić, obszukać i obmierzyć - dołączyć do podzbioru leksemów charakteryzujących ukierunkowanie a kcji (Wiśnicki 2009: 145), tzn. do formacji typu: obsiać, obrównać, obwąchać.

Po tych przegrupowaniach spośród nazw czynności przeprowadzonych „metodycznie" z prefiksem $o b(e)$ - nie zostaje ani jedna.

Poddane analogicznym procedurom weryfikacyjnym formacje z przedrostkiem wy- (wyjeść, wymyć, wyżąć) uzupełniłyby skład wskazujących maks smalną efektyw no ść (por. s. 76-77), podobnie jak czasownik przejeść 'jedząc, wyczerpać, zużyć zapasy'. Inne derywaty utworzone afiksem prze- powinny być włączone, razem z czasownikiem rozprzedać, do szeregowo-kompletywnych (przepytać, przestuchać, przeszukać). Czasownik rozpracować, ewoluujący ku znaczeniu 'zdemaskować' można wyłączyć spośród derywatów prefiksalnych wymiennych jako silnie zleksykalizowany. Na marginesie warto odnieść się do uwag Wiśnickiego dotyczących reprezentacji prefiksalnej czasowników intensyfikacji oraz metodyczności akcji. O intensyfikacji pisze autor, że:

Do tworzenia leksemów o wyżej opisanej wartości znaczeniowej używa się przede wszystkim prefiksu prze-, choć w sumie tę relację semantyczną może reprezentować aż dziewięć prefiksów (Wiśnicki 2010: 86).

$\mathrm{W}$ innym miejscu dodaje:

[...] element znaczeniowy 'uintensywnienie akcji' da się odnaleźć $\mathrm{w}$ wielu przedrostkach rodzimych, zupełnie inaczej niż było to w wypadku czasowników transformatywnych. Świadczy to o tym, że ta relacja semantyczna jest najbardziej uniwersalna ze wszystkich występujących $\mathrm{w}$ derywacji prefiksalnej wymiennej. Tak wielkiej liczby prefiksów nie można znaleźć w żadnej innej relacji tu opisanej (Wiśnicki 2010: 88).

Podobną opinię, ale już bez tak daleko idącego wniosku, wyraża w komentarzu do opisu strukturalnego derywatów należących do wyodrębnionej przez niego grupy metodyczności akcji:

Zastanawia [...] duża liczba przedrostków stosowanych do wyrażenia dominanty leksykalnej 'wykonać coś dokładniej niż na to wskazuje podstawa". Skoro bowiem w całym SGS znalazło się tylko 26 czasowników, które wyrażają taką właśnie akcję, zastosowanie aż pięciu prefiksów można uznać za nadmiar bogactwa (Wiśnicki 2010: 146).

Choć autor się pomylił¹4, jego niepokój jest zrozumiały. Nawet pobieżny przegląd struktury derywatów prefiksalnych wymiennych pozwala zauważyć, że odznaczają się one nieporównanie mniejszym zróżnicowaniem przedrostków niż ich podstawy słowotwórcze. Prawidłowość ta obejmuje grupy semantyczne o dużej liczebności

14 Wyliczenie tekstowe, tabela i wykres wskazują na cztery przedrostki (wy-, prze-, ob(e)-, roz-). 
(dystrybutywne, transformatywne, suplementarne) i w ślad za tym - wyższej randze semantycznej. Taka sytuacja wskazywałaby na wysoki stopień specjalizacji formantów w całym podzbiorze. Różnorodność strukturalną intensyfikacji i metodyczności trudno więc na pierwszy rzut oka zrozumieć. Wydaje się jednak, że oba zjawiska mają wspólny mianownik - znaczny, a przy tym wyjątkowy na tle innych podklas rozrzut wykładników derywacyjnych, co niekoniecznie świadczy o uniwersalności semantycznej. Równie dobrze bowiem może wskazywać na błąd klasyfikacyjny autora. Za taką hipotezą przemawiają rozbieżne opinie badaczy opisujących te zjawiska ${ }^{15}$, jak również niejednoznaczne definicje słownikowe.

5. Uważna, wielostronna analiza derywatów prefiksalnych wymiennych, ujętych w literaturze przedmiotu (w dużej jej części - jeszcze niewydzielonych spośród prefiksalnych dodatnich) jako nazywających intensywność akcji, jak również efektywność, metodyczność, kompletywność i ukierunkowanie działania, upoważnia do istotnych przegrupowań semantycznych. Propozycje zmian klasyfikacyjnych wynikają w pewnym stopniu z definicji leksykograficznych, z kontekstów, które je uzupełniają, a ponadto $z$ analiz logicznych. Niekiedy trzeba było odwołać się do własnej intuicji językowej. W sytuacji, kiedy nie dysponujemy precyzyjnymi, powszechnie przyjętymi narzędziami opisu semantycznego, także to kryterium można uznać za równoprawne z pozostałymi.

Przeprowadzone analizy prowadzą do następujących wniosków:

5.1. Wśród derywatów prefiksalnych wymiennych nie ma czasowników nazywających intensywność akcji; znajdziemy je wśród struktur prefiksalnych dodatnich (leczyć $\rightarrow$ podleczyć) oraz prefiksalno-postfiksalnych (pracować $\rightarrow$ napracować się). Jeśli natomiast badane struktury są derywatami prefiksalnymi wymiennymi (napetnić $\rightarrow$ przepetnić), wyrażają najczęściej efektywność czynności.

5.2. Kategoria efektywności jest wyraźnie niedowartościowana $w$ istniejących opisach. Łatwo w niej wyodrębnić trzy podklasy formacji o wyspecjalizowanych semantycznie prefiksach:

- o wysokiej efektywności (domyć, pomordować);

- o nadmiernej efektywności (przepłacić, przechwalić, przesolić);

- o maksymalnej efektywności (wybić, wyginąć, wytrućc ${ }^{16}$.

5.3. Nie można udowodnić autonomii semantycznej podgrup czasowników nazywających metodyczność oraz kompletywność akcji. One także powinny zostać włączone do struktur nazywających efektywność czynności, co wzmocni jej rangę. Dodajmy, że taka klasyfikacja zwalnia od odpowiedzi na pytanie, dlaczego pewne

15 Metodyczności akcji nie dopatruje się w nich Krupianka (1969), Śmiech (1986: 84) widzi w nich raczej podstawowy składnik semantyczny 'dookoła', a dla Wróbla (1998: 553) są to przykłady „wyrażania aktywnego stosunku subiektu do wyróżnionego obiektu przy kompletnym, wyczerpującym wykonywaniu akcji podstawowej".

16 Z powodów podanych na s. 77 pomijamy „niską efektywność” akcji. 
podgrupy są tak „podejrzanie” różnorodne strukturalnie: otóż dlatego, że nie podano wystarczających powodów, by je wyodrębnić.

5.4. Nieporozumieniem jest mówienie o nazywaniu niskiej intensywności przez pewne przywoływane w opisach struktury. Jeżeli bowiem coś jest intensywne, czyli 'odznacza się wysokim natężeniem', to nie można mu przypisać „niskiego wysokiego natężenia". Gdyby nawet przystać na takie definicje, to elementy składowe tej klasy zostałyby pominięte jako prefiksalne dodatnie, podobnie jak formacje nazywające niską efektywność działania, choć w wyrażeniu tym nie ma sprzeczności logicznej.

5.5. Derywaty typu przepytać, przeszukać, przeegzaminować, przebadać należy zaliczyć do szeregowo-kompletywnych, nazywających czynność wykonywaną kolejno na wielu obiektach. Tak właśnie, naszym zdaniem - trafnie, kwalifikuje je Przybylska (2006: 165). Składnik znaczeniowy 'starannie' czy 'skutecznie' trudno uznać za dominujący.

Interesujące byłoby skonfrontowanie wszystkich klas semantycznych wydzielonych $\mathrm{w}$ istniejących opisach $\mathrm{z}$ derywatami prefiksalnymi wymiennymi $\mathrm{w}$ innym języku (innych językach). Wynik takiego porównania przeprowadzonego na dużej próbie materiałowej pozwoliłby dopiero orzec o uniwersalności (lub jej braku) samej techniki słowotwórczej i klasyfikacji znaczeniowej opartej na kryteriach morfologicznych ${ }^{17}$.

\section{Literatura}

Krupianka A., 1969, Formacje czasownikowe z przedrostkiem o- (ob-) w języku polskim, Toruń.

PrZYbylska R., 2006, Schematy wyobrażeniowe a semantyka polskich prefiksów czasownikowych do-, od-, prze-, roz-, u-, Kraków.

SGS: M. SKARŻYŃSKI (red.), Słownik gniazd słowotwórczych współczesnego języka ogólnopolskiego, t. III: Gniazda odczasownikowe, Kraków 2004.

SJPD: W. Doroszewski (red.), Słownik języka polskiego, Warszawa 1958-1969.

SJPSz: M. Szymczak (red.), Słownik języka polskiego, Warszawa 1978-1981.

ŚmieCH W., 1986, Derywacja prefiksalna czasowników polskich, Wrocław.

USJP: S. Dubisz (red.), Uniwersalny słownik języka polskiego, Warszawa 2003.

Wiśnicki M., 2009, Derywacja prefiksalna wymienna czasowników polskich $w$ świetle danych gniazdowych, „LingVaria” nr 1 (7), s. 139-150.

WiśNICKI M., 2010, Derywacja prefiksalna wymienna w czasownikach polskich na materiale gniazdowym, Uniwersytet Warszawski, rozprawa doktorska, mszps.

17 Próba porównawczego zbadania problemu została podjęta w przygotowywanej monografii $\mathrm{La}$ dérivation par échange de préfixes au sein du système dérivationnel polonais et français. 
Wróbel H., 1984, Słowotwórstwo czasownika, [w:] R. Grzegorczykowa, R. Laskowski, H. Wróbel (red.), Gramatyka współczesnego języka polskiego. Morfologia, Warszawa, S. $467-506$.

Wróbel H., 1998, Czasownik, [w:] R. Grzegorczykowa, R. Laskowski, H. Wróbel (red.), Gramatyka współczesnego języka polskiego. Morfologia, Warszawa, s. 536-583.

\section{Do derivatives created by exchange of prefixes express intensity? Summary}

The paper aims to clarify the misunderstandings concerning the semantic description of derivative verbs created through exchange of prefixes. The description of a class of verbs which up to now have been regarded as expressing the intensity of an action (e.g. przekarmić 'to overfeed', przesolić 'to oversalt') had to undergo deep changes, including the elimination of lexemes which were created using two morphemes simultaneously (napracować się 'to have worked a lot' $<$ pracować 'to work'). A detailed analysis has enabled us to prove that where others saw intensity, there was in fact effectiveness. Derivatives included in this category express three grades of effectiveness: high (as in ubawić się 'to have rather enjoyed oneself', wybiegać się 'to have run enough'), excessive (as in przesolić 'to oversalt', zapić się 'to loose life due to alcohol addiction') and maximal (wytruć 'to poison everyone', domyć 'to wash something clean'). Moreover, other lexemes need to be included in this class, namely those which are incorrectly seen as determining methodicalness (objeść 'to eat all of someone's food'), as well as exhaustivity (wybić 'to kill everyone', wyniszczyć 'to thoroughly destroy'). Such a description will promote effectiveness, while eliminating small semantic sub-groups that are not uniform in their structure. 